\title{
21. GUSTAVE SERDMAN (ca. 1891), CABALLERO DE LA REAL ORDEN DE CARLOS III.
}

\author{
Antonio GONZÁLEZ BUENO
}

El 21 de enero de 1891, Miguel Colmeiro (1816-1901), director del Real Jardín de Madrid, acusa recibo al Director general de Instrucción Pública, de «una colección de la Flora de Finlandia y catálogo de la misma». El procedimiento por el que este herbario llegó al Real Jardín estuvo vinculado con una operación diplomática que reportó para Gustave Serdman, la cruz de Caballero de la Orden de Carlos III.

El trámite burocrático que llevó a otorgar tal recompensa al autor del herbario de Finlandia comienza un año atrás; el 5 de noviembre de 1890, el Ministro de Estado traslada al de Fomento una comunicación del cónsul de España en Heisingforz manifestando que el vice-cónsul de Italia en aquella localidad ofrece ceder a España su colección finlandesa de plantas secas «y que su dueño (...) como hombre rico que es, quedaría muy contento y satisfecho con una condecoración nuestra que armonizase con la Corona de Italia, que ya le dio su país, á consecuencia de haberle regalado una colección de pescados de los mares del Norte.» ${ }^{1}$ Tan extraña solicitud llevó al Ministerio de Fomento a solicitar (18-XI-1890) una valoración del «obsequio» a la comisión de catedráticos de Historia Natural de la Universidad Central; tal reunión tuvo lugar pocos días después (17-XII-1890), en ella se valoró positivamente la petición de G. Serdman solicitando para él las condecoraciones de Isabel la Católica o de Carlos III, el informe fue elevado por el Rector de la Universidad Central el 14 de enero de 1891.

La oferta es aceptada por parte española, tras los trámites de rigor, un decreto de $27 \mathrm{de}$ septiembre de 1891 concede al vice-cónsul italiano la cruz de la Orden de Carlos III; meses antes (5-VIII-1891) el consulado de España en Helsingforz comunica el envío de la caja con los pliegos, vía Barcelona, con destino al Museo de Ciencias Naturales de Madrid. El 15 de septiembre de 1891 , G. Serdman recibe el diploma que acredita su condecoración «por manos de nuestro Cónsul en Helsingfors, inteligente iniciador de este asunto.»

\section{NOTA}

1. El «Expediente sobre la donación al Estado de una flora de Finlandia» se conserva en el Archivo General de la Administración (Alcalá de Henares), Educación, leg. 6509.

Aceptado para su publicación en Abril de 1995

Dirección del autor. Departamento de Farmacia y Tecnología Farmacéutica (Historia de la Farmacia). Facultad de Farmacia. Universidad Complutense. 28040, Madrid. 